\title{
Wybrane aspekty bioinspiracji w rozwoju przemysłu
}

\section{Selected sides of bioinspiration in the industrial development}

\section{Streszczenie}

Wszechświat funkcjonuje zgodnie z prawami fizyki, które tworzą sztywne relacje pomiędzy zjawiskami. Istniejący od wielu lat stan quasi równowagi został naruszony przez negatywne oddziaływanie zanieczyszczeń przemysłowych i komunalnych na środowisko naturalne. Rosnący poziom zanieczyszczeń stanowi zagrożenie dla Środowiska naturalnego a tym samym funkcjonowania człowieka oraz wszystkich organizmów żywych i dalszego rozwoju naszej cywilizacji. Jednym $z$ racjonalnych rozwiązań $w$ istniejącej sytuacji jest wykorzystanie wyników badań „bioniki”, nauki, która bada struktury, materiały i procesy występujące w przyrodzie w celu wykorzystania wyników w dalszym rozwoju techniki. Należy podkreślić, że możliwy jest bionicznie inspirowany dynamiczny rozwój techniki i produkcji przemysłowej przy równoczesnym korzystnym oddziaływaniu na stan Środowiska naturalnego.

Słowa kluczowe: bionika; bioinspiracje; przemysł 4.0; sztywność; odporność na drgania; zużycie; wytwarzanie przyrostowe

\begin{abstract}
The universe is ruled by the universal laws of physics creating fixed relations between the phenomena. This quasi balanced, well established state has been disturbed by the negative impact of the industrial and urban pollution on the Nature environment. The growing level of contamination has become a hazard for the nature environment and for all live creatures, threatening sustainable progress of our civilization. One rational solution comes to mind, making use of the bionic science which investigates structures, materials and processes taking place in the nature in order to utilize the obtained results for the technological progress. It should be emphasized that it is possible to achieve bionic-inspired progress in technology and the industrial production with simultaneous advantageous impact on the Nature environment.
\end{abstract}

Keywords: bionic science; bioinspiration; industry 4.0; rigidity; resistance to vibration; wear; incremental manufacturing

\section{Wprowadzenie}

Zgodnie z poglądami wielu kosmologów, historyków nauki, fizyków wszechświat ukształtował się w wyniku wielkiego wybuchu, który miał miejsce ok. 13,7 miliarda lat temu. Od wielkiego wybuchu Wszechświat rozszerza się i ochładza i funkcjonuje zgodnie z prawami fizyki, które tworzą sztywną strukturę i relacje pomiędzy zjawiskami. Jeżeli ta struktura zostałaby naruszona to Wszechświat nie mógłby istnieć w obecnej postaci i nie mogłoby powstać życie w obecnej postaci oparte na chemii węgla [1 $\div 4]$. Gdyby stosunek sił elektromagnetycznych do sił grawitacji był mniejszy (np. ok. 10 $0^{33}$ ), gwiazdy spalałyby się wielokrotnie szybciej, co uniemożliwiłby powstanie węgla. Podobnie ważna jest wartość silnych i słabych oddziaływań jądrowych. Gdyby silne oddziaływania jądrowe były większe o $2 \%$ niż obecnie, nie mogłyby powstać protony a tym samym i atomy pierwiastków chemicznych. Gdyby słabe oddziaływania jądrowe były słabsze niż obecnie to cały wodór zamieniłby się w hel i nie powstałaby woda niezbędna do życia. Podobnych relacji we wszechświecie jest dużo więcej $[1 \div 4]$. Omawia je w swojej książce prof. Michał Heller [1]. W takiej strukturze praw i relacji fizycznych kształtował się Wszechświat. A ok. 5 miliardów lat temu zaczyna się historia naszej planety: "Ziemi”.

Wszystkie procesy zachodzące $\mathrm{w}$ środowisku naturalnym podlegają tym samym prawom fizycznym co cały Wszechświat. Dlatego dla każdego organizmu w środowisku naturalnym (oczywiście również dotyczy to człowieka, który jest elementem Środowiska naturalnego) istnieją czynniki ograniczające jego życie, funkcjonowanie w pełni zdrowia oraz śmierć, ale długość i komfort życia w zależności od lokalnych i globalnych czynników ograniczających (np. stężenia szkodliwych substancji w powietrzu, wodzie, pożywieniu) może zmieniać się w szerokim zakresie. W początkowym okresie rozwój homo sapiens dokonywał się coraz szybciej, ale nie naruszał równowagi w środowisku naturalnym. Zmiany w środowisku naturalnym nie przekraczały możliwości adaptacyjnych organizmów żywych. Sytuacja zmieniła się skokowo od momentu wynalezienia silnika parowego przez Thomasa Newcomena (1712 r.), udoskonalonego

Prof. dr hab. inż. Adam Ruszaj - Politechnika Krakowska oraz Państwowa Wyższa Szkoła zawodowa w Nowym Sączu.

Autor korespondencyjny/Corresponding author: ruszaj@mech.pk.edu.pl, aruszaj@pwsz-ns.edu.pl 
przez Jamesa Watta w 1763 r., co zapoczątkowało pierwszą rewolucję przemysłową (Przemysł 1.0). Nastąpił gwałtowny wzrost produkcji przemysłowej i związane z tym zapotrzebowanie na energię. Energia była i jest jeszcze głównie uzyskiwana przez spalanie węgla, ropy naftowej i gazu ziemnego. Związana z tym emisja zanieczyszczeń gazowych i pyłów do atmosfery, odprowadzanie, ścieków i odpadów stałych z zakładów przemysłowych i gospodarstw indywidualnych, powszechne stosowanie środków ochrony roślin znacząco zmieniły warunki funkcjonowania ekosystemów zarówno w skali lokalnej, jak i globalnej. Zmiana tych warunków jest tak szybka, że dużo organizmów żywych nie jest w stanie ewolucyjnie się do nich przystosować i muszą funkcjonować w warunkach granicznych. Oczywiście rozwoju gospodarczego nie można zatrzymać, wymuszają go wciąż rosnące potrzeby już 7 miliardów ludzi, z których każdy potrzebuje pożywienia, ubrania, dobrze wyposażonego mieszkania, często samochodu, motoru, roweru itp. Obok lokalnych zagrożeń dla środowiska naturalnego pojawiły się poważne zagrożenia globalne: „efekt cieplarniany”, "dziura ozonowa”, „kwaśne deszcze” itp., które również wpływają istotnie na środowisko naturalne.

W obecnej sytuacji nasuwają się dwa bardzo ważne dla naszej cywilizacji kierunki działania:

- ochrona środowiska naturalnego, w każdym aspekcie, w celu zahamowania zmian klimatycznych i ograniczenia zagrożeń dla organizmów żywych, które nie są w stanie ewolucyjnie przystosować się do zmieniających się warunków życia;

- większe niż obecnie wykorzystanie w rozwoju naszej cywilizacji (również techniki czy informatyki) rozwiązań, które wypracowała Natura w procesie ewolucji. Każdy gatunek zawiera w sobie cenną informację o charakterze konstrukcyjnym, technologicznym, procesowym, informatycznym itp. - musimy tylko nauczyć się ją wykorzystywać.

Analiza przyczyn zagrożeń dla środowiska naturalnego wskazuje, że na czołowych miejscach znajduje się: produkcja energii z wykorzystaniem paliw konwencjonalnych (ropa naftowa, węgiel, gaz ziemny), wytwarzanie specjalnych materiałów, środki ochrony roślin oraz nieracjonalne wykorzystanie wyprodukowanej energii w wyniku stosowania nieoptymalnych rozwiązań konstrukcyjnych.

\section{Charakterystyka rozwoju przemysłu}

Jak już wspominano powyżej globalny i lokalny negatywny wpływ przemysłu na środowisko naturalne rozpoczął się w okresie tzw. I-szej rewolucji przemysłowej, za początek której uważa się wynalezienia silnika parowego przez Thomasa Newcomena (1712 r.), udoskonalonego przez Jamesa Watta w 1763 r. XVIII wiek (tzW. Przemysł 1.0) [5]. Wymuszony potrzebami społecznymi - wzrost liczby ludności, wzrost poziomu życia - dynamiczny rozwój przemysłu był i jest kontynuowany. Na początku XX wieku rozpoczęła się produkcja masowa (np. powstały Zakłady Forda), dokonywała się elektryfikacja, co spowodowało dalszy dynamiczny rozwój przemysłu utożsamiany z II rewolucja przemysłową (tzw. Przemysł 2.0). W latach $70 \mathrm{XX}$ wieku obserwujemy dynamiczny rozwój automatyzacji produkcji przemysłowej (tzw. III-cia rewolucja przemysłowa - Przemysł 3.0). Obecnie też obserwuje się dynamiczne zmiany w produkcji przemysłowej przejawiające się pojawieniem: systemów cyber-fizycznych, systemów dynamicznego przetwarzania danych, robotów autonomicznych. Zmiany te wskazują na to, że uczestniczymy w IV rewolucji przemysłowej (tzw. Przemysł 4.0).

Według [5] Podstawowe zasady koncepcji Przemysłu 4.0 to: współdziałanie (1), wirtualizacja (2), decentralizacja (3), ocena zdolności w czasie rzeczywistym (4), orientacja na usługi (5), modułowość (6). Filarami tak rozumianej koncepcji rozwoju przemysłu są [5]: 1. Autonomiczne Roboty, 2. Symulacje, 3. Pozioma i pionowa integracja softwarowa, 4. Przemysłowy Internet rzeczy, 5. Cyber bezpieczeństwo, 6. Chmura, 7. Zastosowanie metod wytwarzania przyrostowego, 8. Rzeczywistość rozszerzona, 9. Big data i analityka [5]. W Przemyśle 4.0 technologie przyrostowe będą używane do produkcji pełnych serii wyrobów cechujących się złożonym kształtem i małą masą. Zastosowanie technologii przyrostowych do wytwarzania części zamiennych ma skracać też czas przestoju maszyn. Czyli metody przyrostowe wykorzystywane dotychczas głównie w fazie rozwoju wyrobu (Rapid Prototyping) zastosowane zostaną w produkcji (Rapid Manufacturing). Należy sobie uświadomić, że wymienione powyżej filary Przemysłu 4.0 mają liczne bardzo ważne powiązania z Naturą (bioniką). Przede wszystkim metody wytwarzania (produkcji) wypracowane przez Naturę w procesie ewolucji są metodami przyrostowymi. Opracowane i stosowane obecnie metody pozwalają na wytwarzanie elementów nie tylko w skali makro, ale również w skali mikro i Nano $[6,7]$.

Jeżeli przyjmiemy, że "Natura” wybrała racjonalny sposób budowania obiektów, to na rozwój metod wytwarzania przyrostowego powinien być położony szczególny nacisk. Należy również sobie uświadomić, że w każdym z wymienionych filarów rozwoju koncepcji Przemysłu 4.0 ważną role odgrywają systemy informatyczne. A najdoskonalsze systemy informatyczne sterujące "produkcją organizmów żywych”, produkcją wszelkich materiałów oraz przebiegiem procesów życiowych stworzyła NATURA. Innymi słowy, w realizacji koncepcji Przemysłu 4.0 nie można pominąć rozwoju informatyki technicznej w coraz większym zakresie inspirowanej przez badania w obszarze informatyki biologicznej. Przewiduje się, że dzięki tym badaniom może zdołamy zbudować w przyszłości sztuczne systemy działające na tej samej zasadzie co biologiczne systemy informatyki i będziemy mogli tak je zaprogramować, aby zamiast białek wytwarzały np. cząstki tworzyw sztucznych czy innych materiałów i od razu organizowały je w gotowe produkty, "kiełkujące" ze sztucznej cytoplazmy [8].

W realizacji procesów produkcyjnych Przemysłu 4.0 podstawową role odgrywają roboty (autonomiczne), których rozwój i doskonalenie może racjonalnie być inspirowane przez zjawiska, procesy rozwiązania występujące

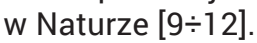

Analiza wpływu przemysłu na stan środowiska naturalnego wskazuje, że występuje zbieżność pomiędzy działaniami zmierzającymi do ochrony środowiska naturalnego oraz koncepcją rozwoju Przemysłu 4.0. Zbieżność ta przejawia się w działaniach zmierzających do zmniejszenia zapotrzebowania na energię oraz optymalnego nią gospodarowania. Należy tutaj przypomnieć, że ok. $40 \%$ wyprodukowanej energii „tracimy” w wyniku procesów tarcia oraz przedwczesnego zużywania się elementów maszyn i urządzeń. Zmniejszenie tych strat energetycznych można osiągnąć przez zastosowanie inspiracji biologicznych zapewniających:

- poprawę właściwości mechanicznych elementów maszyn przy równoczesnym zmniejszeniu ich masy (tzw. konstrukcje lekkie) i zwiększenia okresu ich eksploatacji; należy pamiętać, że zmniejszenie masy elementów (optymalna struktura lub miniaturyzacja) prowadzi do zmniejszenia zapotrzebowania na materiały, których produkcja

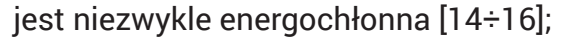

- optymalizację kształtu elementów w celu zmniejszenia oporów ruchu (np. samochody, samoloty, statki) co przekłada się na zmniejszenie zużycia paliwa (energii) [15];

- optymalizację kształtu narzędzi (np. górniczych czy rolniczych) w celu zmniejszenia zużycia energii (do 15\%) 
podczas pracy (np. wiercenia geologiczne, pobieranie próbek przez sondy kosmiczne, koszenie, uprawa gleby itp.) $[17,18]$;

- optymalizację struktury warstwy wierzchniej elementów współpracujących w celu zmniejszenia tarcia a tym samym zmniejszenia zużycia energii oraz zużycia tych elementów - nawet o 53\% [19];

- optymalizację struktury warstwy wierzchniej topatek turbin energetycznych $\mathrm{np}$. elektrownie wiatrowe w celu zwiększenia ilości energii kinetycznej wiatru (nawet o 15\%) przejmowanej przez łopatkę [21].

Podsumowując powyższe rozważania można stwierdzić, że naturalnym 10-tym FILAREM rozwoju Przemysłu 4.0 jest BIONIKA.

\section{Bionika a rozwój systemów technicznych}

Nie wszyscy uświadamiają sobie, że w środowisku naturalnym można znaleźć optymalne rozwiązania wielu problemów technicznych. Badaniami ukierunkowanym na szukanie rozwiązania problemów technicznych w organizmach żywych zajmuje się dziedzina nauki nazywana bioniką [13:15].

Bionika jest interdyscyplinarną dziedziną nauki, która zajmuje się badaniami organizmów żywych (roślin i zwierząt) z punktu widzenia możliwości wykorzystania rozwiązań powstałych w wyniku trwającej kilka miliardów lat ewolucji w rozwiązaniach technicznych, ekonomicznych czy społecznych. Nazwa „bionika” pochodzi od słów greckich: bios - życie oraz mimesis - naśladować. W literaturze spotyka się również inne nazwy np.: biomimetyka, biomimikra, inżynieria bioniczna. Od niepamiętnych czasów ludzie czerpali swoje inspiracje z przyrody. Już człowiek pierwotny, ściśle uzależniony od matki natury i jej kaprysów, starał się ją wykorzystywać i naśladować. Dziś każda dziedzina naszego życia pozostaje pod jej wpływem, ponieważ ewolucja ze względu na praktycznie nieograniczony czas wykształciła niedoścignione wzorce, które do dziś wpływają na dzieła ludzkie. Żaden obiekt, maszyna czy proces opracowane przez człowieka nie dorównuje doskonałości organizmów żywych, które stworzyła ewolucja. Fascynację przyrodą potwierdza Albert Einstein, który powiedział: „Jednej rzeczy nauczyłem się w moim długim życiu: że cała nauka w konfrontacji z rzeczywistością wydaje się prymitywna i dziecinna".

W obszarze techniki bionika integruje środowiska naukowe i inżynierskie, gdyż racjonalne korzystanie z rozwiązań Natury wymaga pracy zespołowej i współpracy różnych specjalistów (inżynier, informatyk, chemik, fizyk, biolog, lekarz, ekonomista, socjolog itp.). Bionika daje również nowe argumenty do ochrony i szacunku dla środowiska naturalnego, które jest i powinno być w coraz większym zakresie źródłem inspiracji i wiedzy, wykorzystywanej przez nas dotychczas w niewielkim stopniu. W obszarze zastosowań technicznych szczególnie ważna jest współpraca biologów i inżynierów, gdyż żaden $z$ nich nie rozwiąże samodzielnie problemu. Inicjatywa może być zarówno po stronie biologów, jak i inżynierów. Jeżeli inżynier określi charakterystyki i funkcje obiektu technicznego to biolog wybierze adekwatne rozwiązania, wypracowane przez Naturę. Jeżeli biolog opisze atrakcyjny proces czy strukturę konstrukcyjną to inżynier powinien znaleźć ich racjonalne zastosowanie w technice. Homo sapiens od początku swojego istnienia wzorował się w miarę możliwości na organizmach i zjawiskach występujących w przyrodzie. Już w starożytnej legendzie o Dedalu i lkarze zawiera się zainteresowanie lataniem wynikające z obserwacji ptaków. Wybitni uczeni jak Leonardo da Vinci, Johannes Kepler, Luigi Galvani czy Jean Louis Marie Poiseuille, z racji realizowanych prac uważani są dzisiaj za prekursorów bioniki.
Obecnie można podać wiele przykładów wykorzystania osiągnięć bioniki w wielu dziedzinach od budownictwa przez informatykę, medycynę, przemysł lotniczy, samochodowy do technologii maszyn, ale wciąż wg specjalistów jest to nie więcej niż 10\% możliwych zastosowań. Poniżej podane zostanie kilka przykładów możliwych zastosowań osiągnięć bioniki.

\section{Poprawa właściwości mechanicznych elementów maszyn i narzędzi}

Podstawowe właściwości mechaniczne korpusu obrabiarki to wpływające na wyniki obróbki to, obok parametrów kinematycznych, wytrzymałość, sztywność, odkształcenia, odporność na zużycie elementów współpracujących, zdolność tłumienia drgań. Wszystkie z wyżej wymienionych właściwości można istotnie poprawić wzorując się na makro i mikrostrukturach roślin (drzewa, krzewy, trzcina, kaktus meksykański, liście drzew i kwiatów) oraz zwierząt (szkielet, kości, dzioby tukana lub dzięcioła).

Jest to bardzo ważne bo dzięcioł uderza dziobem nawet 1000 razy na minutę a siła pojedynczego uderzenia wynosi ok. 1 kG i gdyby nie specjalna struktura dziobu oraz układ kości czaszki mózg zostałby na pewno uszkodzony. Ponadto dziób dzięcioła posiada zdolności do samoostrzenia. Dzięki temu podczas uderzenia nie zatrzymuje się gwałtownie, ale przemieszcza się w głąb drewna.

Analogicznie można chronić od drgań obszar obróbki czy obszar pomiaru (głowicę pomiarową, itp.) W zależności od rodzaju elementu i wzorca biologicznego (rys. 1, 2, $3,4)$ bioniczne konstrukcje charakteryzują się zwiększeniem wytrzymałości o 53 $\div 124 \%$, zwiększeniem sztywności o $21 \div 43 \%$, zmniejszeniem masy o $3 \div 43 \%$, zmniejszeniem odkształceń o $16 \div 44 \%$ [14 $\div 16]$. Bioniczne konstrukcje charakteryzują się ponadto zwiększoną odpornością na drgania. W ten właśnie sposób poprawiono właściwości mechaniczne ultra precyzyjnej szlifierki (rys. 5).

W projektowaniu narzędzi rolniczych konieczne jest zapewnienie dużej wydajności i żywotności przy możliwie małym zużyciu energii. Maszyny rolnicze pracują nawet kilkanaście godzin dziennie, dlatego nawet małe oszczędności energii właściwej mogą dawać duże efekty ekonomiczne. Zmniejszenie zużycia energii może wynikać ze zmniejszenia oporów ruchu narzędzia w glebie, co zależy między innymi

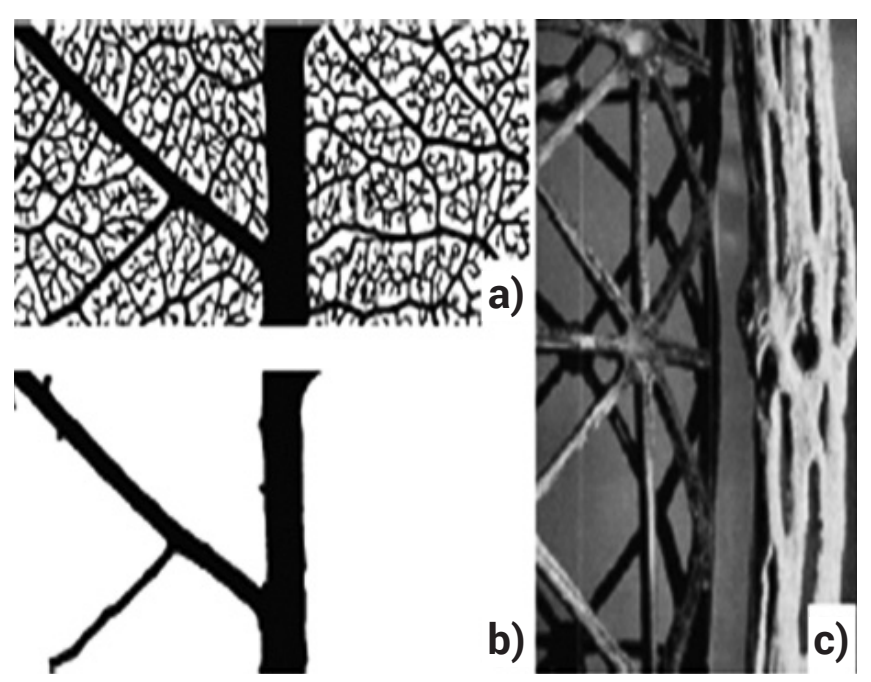

Rys. 1. Sieć użyłkowania liścia Gloeopermum $(\mathrm{a}, \mathrm{b})$ oraz pędu Kaktusa meksykańskiego (c) $[14,16]$

Fig. 1. Nervation of the Gloeopermum leaf $(a, b)$ and of the Mexican cacti shoot (c) $[14,16]$ 


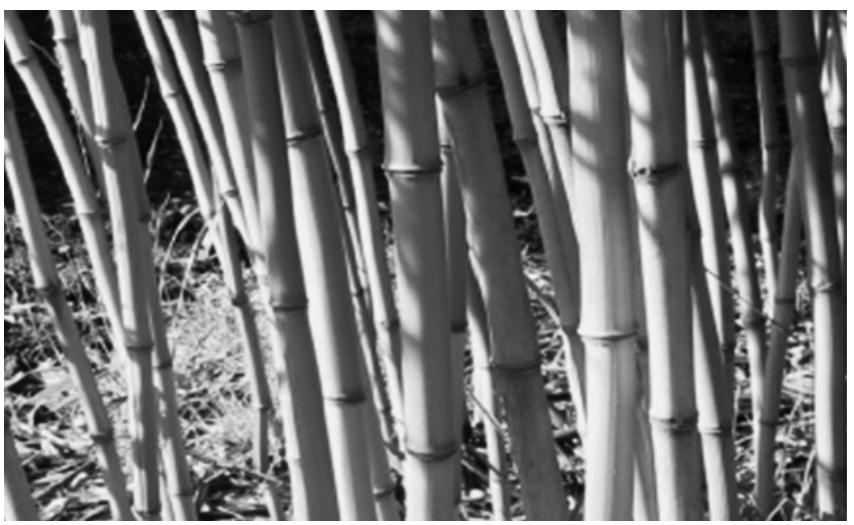

Rys. 2. Bambus pomimo wysmukłej i lekkiej budowy odznacza się bardzo dużą stabilnością i sztywnością $[14,16]$

Fig. 2. Bamboo, despite its slender and lightweight construction, is characterized by very high stability and stiffness $[14,16]$

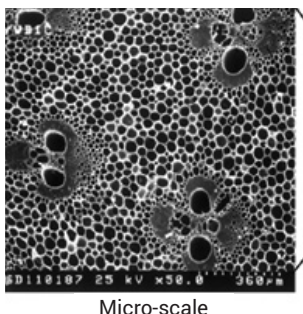

Micro-scale

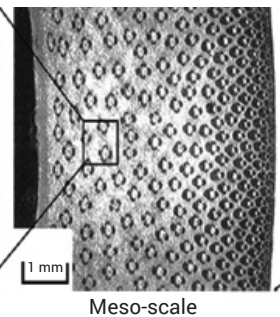

Meso-scale

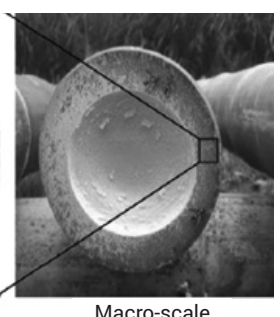

Macro-scale
Rys. 3. Struktura wewnętrzna bambusa w różnych skalach $[14,16]$

Fig. 3. The internal structure of the bamboo in various scales $[14,16]$

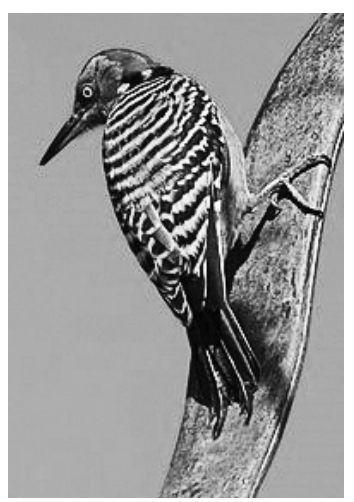

Rys. 4. Dzięcioł - jego czaszka i dziób posiadają specyficzną budowę wewnętrzną umożliwiającą tłumienie drgań. Ponadto układ mięśni i kości czaszki izoluje mózg od źródła drgań i kieruje te drgania w kierunku mięśni karku

Fig. 4. Woodpecker - its skull and beak have specific internal structure which is useful for damping vibrations. Moreover, the muscle and skull system ensures insulation of the brain from the source of vibration and directs vibrations onto the nape muscles

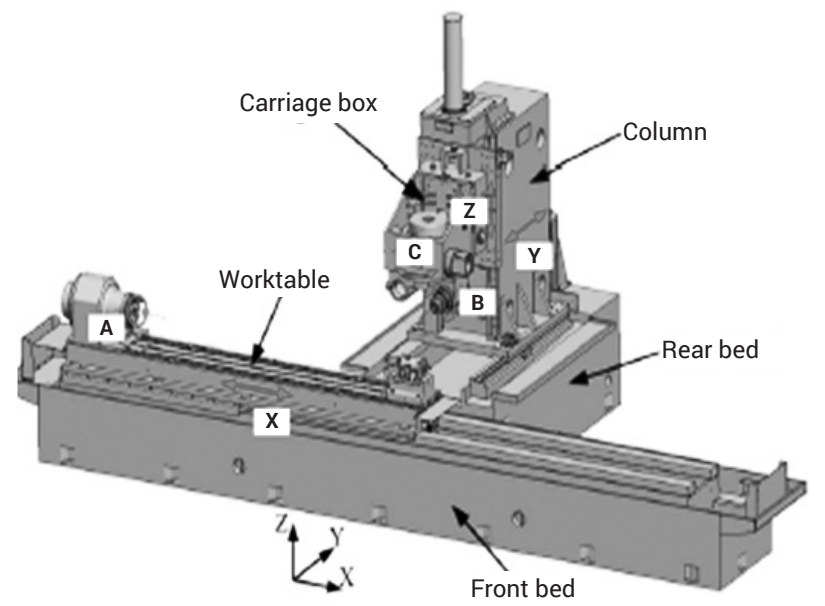

Rys. 5. Ultraprecyzyjna szlifierka; projekt bioniczny inspirowany przez użyłkowanie liści dotyczył kolumny i łoża; maksymalne odkształcenia kolumny zmniejszono o 16,22\%, masę o 1,31\% a sztywność zwiększono o $23,29 \%$, masa łoża zwiększyła się o $0,87 \%$, odkształcenia zmniejszono o 12,07\% a sztywność wzrosła o 12,30\% [16]

Fig. 5. Ultra-precision grinder; the project bio-inspired by the leaf nervation was connected with the column and bed design; the maximum column deformation was reduced by $16.22 \%$, its mass by $1.31 \%$ and rigidity increased by $23.29 \%$, the bed mass was increased by $0.87 \%$, its deformation was reduced by $12.07 \%$ and its rigidity was increased by $12.30 \%$ [16] od kształtu narzędzia. Takim stosunkowo prostym narzędziem jest tarcza tnąca maszyn przeznaczonych do uprawy ściernisk. Maszyny takie mają duże znaczenie przy obróbce dużych obszarów (np. Chiny czy USA). Przystępując do projektowania tarczy tnącej takiej maszyny jako wzorzec biologiczny wybrano łapy kreta (rys. 6).

Analizując budowę przedniej łapy kreta i jej palców opracowano model bioniczny tarczy maszyny rolniczej. Modelowanie kształtu, oporów ruchu i naprężeń przeprowadzono metodą elementów skończonych. W wyniku tej analizy opracowano kształt bioniczny tarczy tnącej i porównano go z kształtem dotychczas stosowanej tarczy (rys. 7).

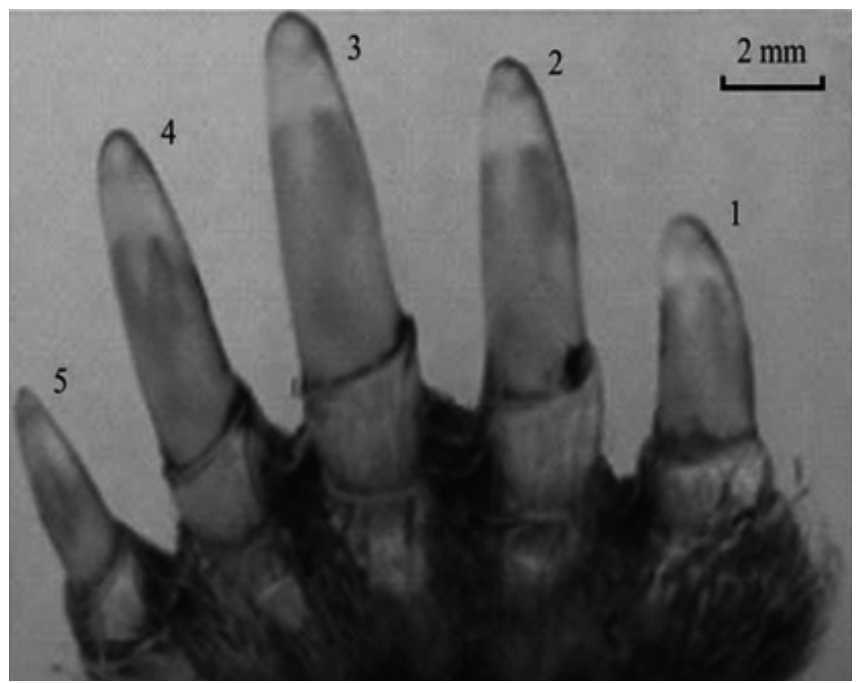

Rys. 6. Przednia łapa kreta [17]

Fig. 6. The front paw of a mole [17]

a)

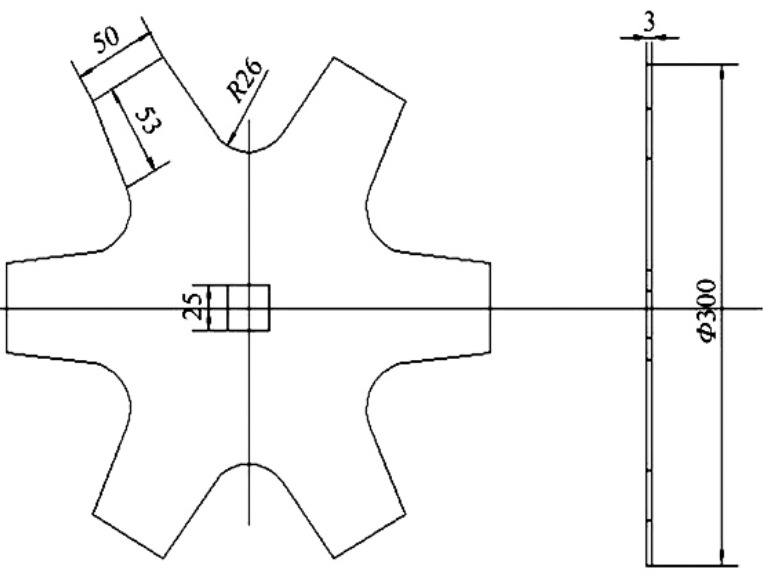

b)

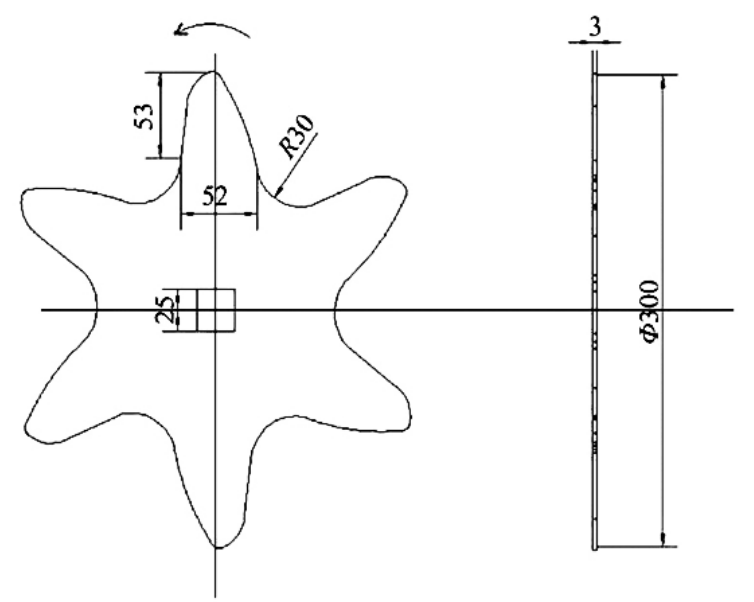

Rys. 7. Model konwencjonalnej (a) i model bionicznej (b) tarczy tnącej maszyny rolniczej [17]

Fig. 7. Model of (a) conventional (b) bionic-inspired agricultural cutting disk [17] 

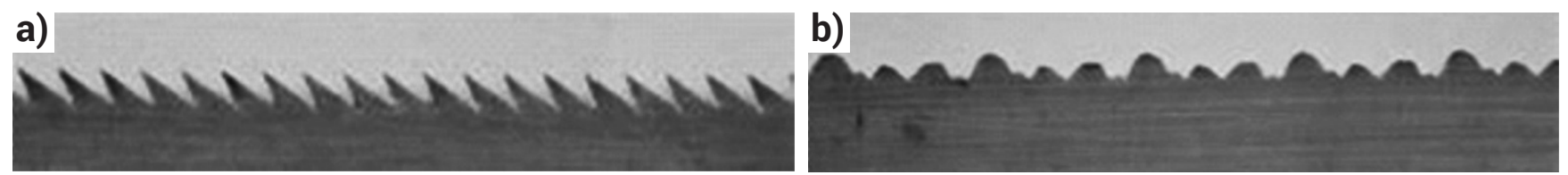

Rys. 8. Ostrze tnące kosy: konwencjonalne (a) oraz bioniczne-wzorowane na budowie szczeki świerszcza (b) [18]

Fig. 8. Cutting blade of a scythe: conventional (a), bio-inspired by the cricket jaw (b) [18]

Z przeprowadzonych obliczeń wynika, że wypadkowe naprężenia (suma naprężeń normalnych i stycznych pochodzących od tarcia) dla tarczy bionicznej są 34.33\% mniejsze niż dla tarczy standardowej. Naprężenia normalne są dla tarczy bionicznej o 22,64\% mniejsze niż dla tarczy standardowej. Natomiast naprężenia w glebie w wyniku oddziaływania tarczy bionicznej są z kolei o 6,87\% większe niż w przypadku tarczy standardowej, co zapewnia tarczy bionicznej większą efektywność rozdzielania i rozdrabniania wierzchniej warstwy np. ścierniska [17].

Inspiracją do zaprojektowania kosy bionicznej były szczęki świerszcza (rys. 8) [18].
Zastosowanie bionicznego rozwiązania umożliwiło zmniejszenie średniej siły cięcia (koszenia) o $28,17 \%$ (z 71,88 N do 51,56 N). Równocześnie zużycie energii zmniejszyło się o 12,85\%. Powyższe efekty wynikają z optymalnego kształtu bionicznej kosy, której ostrza były wzorowane na siekaczach świerszcza. Zęby kosy tradycyjnej były jednorodne i miały kształt pochylonego trójkąta o ostrym wierzchołku. Zęby kosy bionicznej były różnej wysokości i miały kształt wpisany w trójkąt równoramienny. Wierzchołek każdego zęba był zaokrąglony [18].

\section{Podsumowanie}

Bionika oferuje wykorzystanie w szeroko rozumianej inżynierii produkcji rozwiązań wypracowanych przez Naturę w procesie ewolucji. Rozwiązania te są już stosowane w projektowaniu i produkcji elementów lotniczych, samochodowych czy obrabiarkowych (np. lekkie i sztywne korpusy precyzyjnych obrabiarek, cienkościenne, sztywne i wysoko wytrzymałe cylindry, konstrukcje spawane itp.). W niniejszym artykule wykazano, że bionika może zostać efektywnie wkomponowana w trwającą obecnie rewolucję przemysłową (Przemysł 4.0) i stanowić 10-ty filar tej koncepcji rozwojowej. Należy sobie uświadomić, że w koncepcji Przemysłu 4.0 ważną role odgrywają metody wytwarzania przyrostowego oraz systemy informatyczne. A najdoskonalsze systemy wytwarzania przyrostowego oraz systemy informatyczne sterujące "produkcją" organizmów żywych, „produkcją” wszelkich materiałów oraz przebiegiem procesów życiowych stworzyła natura. Innymi słowy, w realizacji koncepcji Przemysłu 4.0 nie można pominąć rozwoju metod wytwarzania przyrostowego oraz informatyki technicznej w coraz większym zakresie inspirowanej przez badania w obszarze informatyki biologicznej. Przewiduje się, że dzięki tym badaniom może zdołamy zbudować w przyszłości sztuczne systemy działające na tej samej zasadzie co biologiczne systemy informatyki i będziemy mogli tak je zaprogramować, aby zamiast białek wytwarzały np. cząstki tworzyw sztucznych czy innych materiałów i od razu organizowały je w gotowe produkty, „kiełkujące” ze sztucznej cytoplazmy.

W realizacji procesów produkcyjnych Przemysłu 4.0 podstawową role odgrywają roboty (autonomiczne), których rozwój i doskonalenie może racjonalnie być inspirowany przez zjawiska, procesy rozwiązania występujące w Naturze. Zatem BIONIKA powinna być 10-tym filarem obecnej rewolucji przemysłowej.

\section{Literatura}

[1] Heller M.: Granice nauki, Copernicus Center Press, Kraków 2014.

[2] De GrasseTyson N., Goldsmith D.: Wielki poczatek - 14 miliardów kosmicznej ewolucji, Prószyński I S-ka, Warszawa 2004

[3] Gates E.: Teleskop Einsteina - w poszukiwaniu ciemnej materii i ciemnej energii we Wszechświecie, Prószyński I S-ka, Warszawa 2010.

[4] Davies P.: Ostatnie trzy minuty, Wydawnictwo CIS, Oficyna Wydawnicza MOST, Warszawa 1995

[5] Sęp J.: Fabryka Przyszłości - czy faktycznie twa czwarta rewolucja przemysłowa?, referat wygłoszony na II Posiedzeniu Sekcji Technologii Komitetu Budowy Maszyn PAN, 1-2.06.2017, Politechnika Rzeszowska.

[6] Tkacz E., Borys P.: Bionika, WNT, Warszawa, 2006.

[7] www.nanoscribe.de

[8] Węgrzyn S., Znamirowski L.: Zarys nanonauki i informatycznych molekularnych nanotechnologii, Wydawnictwa Politechniki Śląskiej, Gliwice 2008.

[9] Wang J., Sato H., Xu Ch., Taya M.: Bioinspired design of tactile sensors based on Flemion, Journal of Applied Physics 105, 083515, 2009, pp. 1-7.

[10] Vincent J.F.V., Clint S.E. Menon C.: Biomimetics of Campaniform Sensila: Measuring Strain from Deformation of Holes, Journal of Bionic Engineering 4, 2007, pp. 63-76

[11] Jaax K.N., Hannaford B.: Mechatronic Design of an Actuated Biomimetic Length and Velocity Sensor, IEEE Transactions on Robotics and Automation, Vol. 20, No. 3, 2004, pp. 390-398.

[12] Quin S., Gaughran W.: Bionics an inspiration for intelligent manufacturing and engineering, Robotics and computer - integrated manufacturing 26, 2011, pp. 620-632
[13] Samek A.: BIONIKA. Wiedza przyrodnicza dla inżynierów, Wydawnictwo AGH, Kraków 2010.

[14] Ruszaj A.: Bionic Impact on Industrial Production Development, Advances in Manufacturing Science and Technology, Vol. 39, No 4, 2015, pp. 5-22.

[15] Shu L.H., Ueda K., Chiu I., Cheong H.: Biologically inspired design, CIRP Annals - Manufacturing Technology 60, 2011, pp. 673-693.

[16] Ruszaj A.: Bioinspiracje w projektowaniu konstrukcji lekkich (Bioinspirations in lightweight construction designing), Mechanik 2016 (2) s. 88-92.

[17] Li M., Chen D., Zhang S., Tong J.: Biomimetic Design of a Stubble - Cutting Disc Using Finite Element Analysis, Journal of Bionic Engineering 10, 2013, pp. 118-127.

[18] Jia H., Li Ch., Zhang Z., Wang G.: Design of Bionic Saw Blade for Corn Stalk Cutting, Journal of Bionic Engineering 10, 2013, pp. 497-505.

[19] Chen Z., Lu S., Song X., Zhang H., Yang W., Zhou H.: Effects of bionic units on the fatigue wear of grey iron surface with different shapes and distributions, Optics \& Laser Technology 66, 2015, pp. 166-174.

[20] Ruszaj A.: Wybrane aspekty bioinspiracji w inżynierii Produkcji (Some aspects of bioinspirations in production Engineering - Part I), Świat Obrabiarek i Narzędzi, Nr 11/12 2015 oraz Nr 1/2 2016.

[21] Ruszaj A.: Some aspects of bioinspirations in energy production and consumptions, Procedia Engineering [online] - 2016, Vol. 157, pp. 465-471, Mat. konf.: IX International Conference on Computational Heat and Mass Transfer, ICCHMT2016, Cracow, Poland, 23-26.05.2016 - doi: 10.1016/j. proeng.2016.08.390. - ISSN 1877-7058 